\title{
Effect of F Score on Stock Performance: Evidence from Indian Equity Market
}

\author{
Trilochan Tripathy ${ }^{1} \&$ Bijon Pani ${ }^{1}$ \\ ${ }^{1}$ XLRI-Xavier School of Management, Jamshedpur, India \\ Correspondence: Trilochan Tripathy, XLRI-Xavier School of Management, Jamshedpur, India. Tel: \\ 916-576-653-161. E-mail: trilochan@xlri.ac.in
}

Received: November 16, 2016

Accepted: December 14, 2016 Online Published: January 10, 2017

doi:10.5539/ijef.v9n2p89

URL: http://dx.doi.org/10.5539/ijef.v9n2p89

\begin{abstract}
This study seeks to examine whether value investing strategy based on F Score when applied to high book to market firms can significantly shift the current and future stock performance in favour of the investor in the Indian market. The study engages the panel data model to analyse the impact of high $\mathrm{F}$ Score on contemporaneous and future stock returns $\left(\mathrm{R}_{t}\right.$ and $\left.\mathrm{R}_{t+1}\right)$, return on equity $\left(\mathrm{ROE}_{t}\right.$ and $\left.\mathrm{ROE}_{t+1}\right)$ and market to book value $\left(\mathrm{MTBV}_{\mathrm{t}}\right.$ and $\left.\mathrm{MTBV}_{\mathrm{t}+1}\right)$ as stock performance measures. The study concludes that high book to market firms with high F Score can shift the distribution of contemporaneous and future stock performances in favour of investors in the Indian market. However such observation is most prominent and statistically significant at higher level when applied to future stock valuation measures than the future stock return as measures of stock performance. The outcome of the study would no doubt help the individual value investors, mutual fund managers and value investing strategists who have presence in the Indian market.
\end{abstract}

Keywords: value investing, F score, firm performance, book to market value, return on equity, high book to price

\section{Introduction}

Emerging equity markets are increasingly seen as important destination for investment in recent decades. One challenge investors especially those in asset management industry face is that of investing in emerging market deep value stocks. Literature suggests that these stocks are usually categorised as high book to market value and are often illiquid (Fama \& French, 1993; Pontiff \& Lawrence, 1998). Fishing for investment in distressed area of equity markets is difficult for funds that have to commit to scalability and easy liquid redemption norms along with regulatory rules. Alternative investment and private wealth does better in capturing this value tilt in their portfolios. There is larger upside return surprise in distressed stocks as the market has already discounted all the negative news and overpays for any good news, such as earnings surprise or management strategy. But in high growth stocks, good news is already factored in so more good news has limited upside return potential while negative news has bigger downside price movement risk.

The goal of this study is to examine whether value investing as a strategy based on Piotroski Score (F Score) when applied to a broad portfolio of high book to market firms can significantly shift the current and future stock performance in favour of the investor in the Indian market. Value investing in general and application of F Score as a value investing strategy in particular remain mostly limited to trading in the market space. However empirical evidences of the effect of F Score on stock performance are highly scanty, sporadic and mostly remain limited to the developed markets. This paper seeks to fill the gap in literature in demonstrating the effect of $\mathrm{F}$ Score on stock performance in an emerging market context. Firstly, Indian market is an interesting setting to examine the effects of $\mathrm{F}$ score on firm performance due to its regulation, risk, liquidity, growth potential compared to mature and frontier markets. Secondly, there is lack of comprehensive study for Indian markets, where investor's base for retail is expanding but limited to only $0.2 \%$ of its population, while global institutional investors have active participation after liberalization era (Gondhi \& Sarkar, 2011). Further India is a natural choice among the emerging markets due to its strong and consistent growth among its peers.

Engaging panel data model over a period of 6 years on stocks drawn from the third largest stock exchange of the world (National Stock Exchange of India), the study concludes that F Score, when applied to a broad portfolio of high book-to-market firms, can shift the stock performance in favour of investors in the Indian market. F Score 
can also be used stand alone to measure how strong financially companies are in a stock portfolio or for evaluation of an acquisition target or for effect of management decision on long term financial health of the firm. It is a good measure of the financial soundness of a firm based on its bottom up financial data. The outcome of this study would no doubt influence the individual value investors, mutual fund managers and trading strategists who have presence in the Indian market.

The rest of the paper is organized as follows: Section 1 provides a general overview of the research work and discusses the objectives of the study. Section 2 reviews the major literature on value investing and hypotheses development. Section 3 presents the methodology employed in the study. Section 4 presents results of the study. Robustness examination is carried out in section 5. Section 6 concludes the study.

\section{Review of Literature and Hypotheses Development}

The book to market effect is probably one of the oldest effects which has been investigated in financial markets. The bigger the book to market ratio is, the more fundamentally cheap is the stock of the firm. Literature suggests that investors overreact to growth aspects for growth stocks, and value stocks remain thus undervalued (Debondt \& Thaler, 1985; 1987). It is believed that the stock with high market to book value is often financially distressed and thus the larger returns generated by this stock is simply a compensation for risk (Fama \& French, 1993; Pontiff \& Lawrence, 1998). Since many decades, investment analysts worldwide have been adopting this value investing strategies to predict the stock and portfolio returns. Debondt and Thaler (1985 and 1987) also conclude that long term past losers outperform the long term past winners. While Jegadeesh and Titman (1993), report that in an intermediate horizon of three to twelve months, past winners continue to outperform past losers. Jegadeesh and Titman's (2001) study affirms that buying winning stocks and selling losing stocks based on their past performance provides abnormal returns and this zero cost momentum strategy provides abnormal returns. Sehgal and Balakrishnan (2002) report continuation of trend in short term and significant high returns of value investing strategy in Indian market from July 1989 to March 1999 for 364 companies. Fama and French (2012) have added momentum as a fourth factor to their three factor model to explain the excess return. Academic literature on value investing has grown leaps and bounds around the momentum strategies. Many of these studies look at company financial statements as a source of prediction of future stock value and price movement. Lev and Thiagarajan (1993) analysed 12 financial ratios and demonstrated their positive effect on future earnings growth. Ou and Penman (1989) similarly showed the predictive power of financial ratios in a firm's future earnings. Mohanram (2005) used financial statement analysis to show that fundamental factors can help pick winning stocks among low Book to Market stocks (Growth stocks) while Piotroski (2000) used it on high Book to Market stocks (Value stocks). The value investing proposition of Joseph D Piotroski (2000) even though aggressively used in the trading practices, has not been given enough scrutiny in the academic literature. Thus this study employs value investing strategies of Piotroski to bridge the gap in the literature in the emerging market context.

Literature amply evidences that portfolio of high book to market (BM) firms out performs the low BM firms in the future (Rosenberg, Reid and Lanstein (1985), Fama and French (1992, 1993, 1995, 1996 \& 1998), Lakonishok, Shleifer and Vishny (1994), Kothari, Shanken and Sloan (1995)). Fama and French (1992) affirm that firm's book to market, characterised as a variable, measures the financial distress and in turn future stream of returns of the stock required to be fairly compensated for risk. This high future return attribution to high BM stock emanates from both market efficiency and inefficiency. On one hand literature evidences a strong positive relation between $\mathrm{BM}$, leverage, financial leverage and other risk based measures, which ensure the contribution of market efficiency (Fama \& French, 1992; Chen \& Zhang, 1998). On the other, the high BM stocks are often mispriced and these stocks surprise with their quarterly earnings and dividends, which remains un-noticed by the market participants (La Porta et al., 1997). Empirical evidence also suggests that market doesn't fully incorporate historical financial information into price formation in future, which shows the inefficiency of the market (Piotroski, 2000). From an investment perspective, financial strategists normally don't choose the poor performing low volume and small capitalised firms (McNichols \& O'Brien, 1997; Hayes, 1998). As the high BM firm managers suffers from credibility issue, their forward looking positive information disclosure fails to change the mood of capital market (Koch, 2002; Piotroski, 2000; Miller, 2002). There have been some studies on effectiveness of Piotroski F Score in emerging market which have been country or region specific. Galdi and Broedel Lopes (2009) study the Brazilian (BOVESPA) market where they found a positive relation of F Score to strong value stocks but when adjusted for arbitrage and short selling constraints of Brazilian market, this excess return disappeared; Asian markets has been studied by Kang and Ding (2005) where they found financially strong firms determined by F Score usually outperform weak firms. While Charles Hyde (2013) uses the MSCI Emerging Market Index for his studies which includes a very small portion of Indian listed firms. 
Based on the research question of how Piotroski Score influences the stock performances in the Indian market, the following two broad hypotheses and six specific hypotheses are examined in this study:

H1a: There is a positive relationship between F Score and contemporaneous stock performance.

H1.1a: There is a positive relationship between F Score \& contemporaneous stock return.

H1.2a: There is a positive relationship between F Score and contemporaneous return on equity.

H1.3a: There is a positive relationship between F Score and contemporaneous market to book value.

H2: Stocks with high BM and high F Score at current period positively influence future stock performance.

H2.1a: Stocks with high BM \& high F Score at current period positively influence future stock return.

H2.1a: Stocks with high BM \& high F Score at current period positively influence future return on equity.

H3.1a: Stocks with high BM \& high F Score at current period positively influence future market to book value.

\section{Materials and Methods}

This section explains about the nature and sources of data used, variables used in the empirical investigation and their construction methodologies, and models engaged in the study.

\subsection{Nature and Sources of Data}

This study is based on secondary annual audited end of the year financial statements data obtained from Centre for Monitoring Indian Economy (CMIE) Prowess data base and Bloomberg. It is a challenge to find correct financial data for Indian companies over a long time frame. Databases that do contain financial information have gaps in this record over the study period. To overcome this problem, we used the Bloomberg data source and merged it with the CMIE to build the final dataset. Dataset looks at the NSE Top 500 companies in India across the whole time frame. These are the top 500 companies by market capitalisation listed on the National Stock Exchange, India. Any firm with missing data or erroneous data in the time line that could not be rectified was removed. After doing so, we were left with 266 companies whose data was available for the entire period of our study (2009 till 2015). This spread of companies covers blue-chip as well as medium and small capitalization companies. In 2009, the largest company in the dataset was Reliance Industries Limited with a market capitalization of approximately 2.5 trillion rupees and the smallest company was Geometric Limited with market capitalization of approximately 900 million rupees. The dataset constitutes 266 companies spreading across 9 different sectors such as basic materials, communications, consumer goods, energy, financials, industrial, technology, utilities and diversified. However, the final data set excludes all banking and financial institutions from our study and thus we are left with 215 firms. The financial data set that is used in this study contains the following variables: stock return, price to book value, return on asset, income before extraordinary items, cash flow from operations, total asset, current asset, current liabilities, long term debt, current ratio, gross margin, total sales, total shares outstanding, operating income, cost of goods sold, sector categories, market capitalisation and age of the firm.

\subsection{Variables Used}

Three stock performance related measures such as stock return, price to book and return on equity are used as dependant variables. The independent variables used in this study are F score, size of the firm, age of the firm and a set of 8 dummy industry variables. The interest variable is F score, which is constructed and used in the model. The stock performance examination is carried out both contemporaneously and with lead indicators of dependant variables. The following subsection presents in detail the F score construction methodology and other variables used in the study.

Following the prescribed scoring methodology of Joseph Piotroski (2000), we have constructed the Piotroski Score (F Score) using the historical financial information from our sample Indian firms. Although Piotroski uses his scoring system on a high book to market portfolio, we have used this on the Top 500 Indian companies listed on the National Stock Exchange of India (NSE) based on the firm's market capitalisation. While constructing the F Score, a scoring system is designed to capture the 9 fundamental signals- 4 profitability signals, 3 leverage and liquidity signals and 2 operating efficiency signals to measure the financial health of the firm. These signals are obtained from the firm's historical information on profitability, financial leverage and operating efficiency measures.

The four profitability signals are obtained from the last reported return on asset (ROA), last reported cash flow from operations $(\mathrm{CFO})$, change in return on asset $(\triangle \mathrm{ROA})$ and last reported income from extraordinary items 
(ACCRUAL). The ROA signal value is 1 if the last reported ROA for the firm is a positive number otherwise 0 . If the last reported cash flow from operations for the firm is positive then CFO signal value is 1 else 0 . If the change in ROA scaled by total asset of the current year from the previous year is positive, then $\triangle$ ROA signal value is 1 else 0 . The ACCRUAL signal value is 1 if last reported income from extraordinary items for the firm is positive, otherwise 0 . Likewise, three leverage and liquidity related signals are change in leverage ( $\triangle$ LEVERAGE), change in liquidity ( $\triangle$ LIQUIDITY) and change in equity ( $\triangle$ Equity). The ( $\triangle$ LEVERAGE) signal value is 1 if the change in long term borrowing scaled by total assets for the previous year is greater than the current year, otherwise 0 . If the difference between current ratio for the current year from the previous year for the firm is positive then, $\triangle$ LIQUIDITY signal value is 1 , else 0 . If the previous year common equity outstanding for a firm is greater than the current year, then $\triangle$ EQUITY signal value is 1 else 0 . Two operating efficiency signals come from change in margin ( $\triangle$ MARGIN) and change in turnover ( $\triangle$ TURNOVER). If the change in total sales scaled by total assets for the current year from the previous year is positive, then ( $\triangle$ MARGIN) signal value is 1 , otherwise 0 . The ( $\triangle$ TURNOVER) signal value is 1 if the change in total sales scaled by total assets for the current year from the previous year is positive, otherwise 0 . Each signal output is expressed in terms of a binary response variable 1 as good and 0 as bad for the firm. The conditions used in estimating individual F Score components are given thereof in the Table 1.

Table 1. Conditions used in estimating individual F Score components

\begin{tabular}{ll}
\hline ROA $>0$ & $\mathrm{IF}($ ROA $>0)$ then 1 else 0 \\
CFO $>0$ & $\mathrm{IF}($ Cash flow from Operations $>0)$ then 1 else 0 \\
Change in ROA & $\mathrm{IF}($ Current Year ROA/Total Asset - Previous Year ROA/Total Asset $)>0$ then 1 else 0 \\
Change in Accruals & $\mathrm{IF}($ CFO- Income before Extraordinary Items $)<0$ then 1 else 0 \\
Change in Leverage & $\mathrm{IF}($ Current Year Long Term Debt/Total Asset - Previous Year Long Term Debt/Total Asset $)<0$ then 1 else 0 \\
Change in Liquidity & $\mathrm{IF}($ Current Year Current Ratio - Previous Year Current Ratio $)>0$ then 1 else 0 \\
Change in Equity & $\mathrm{IF}($ Current Year Shares Outstanding - Previous Year Shares Outstanding $)<0$ then 1 else 0 \\
Change in Margin & $\mathrm{IF}($ Current Year Gross Margin/Total Sales - Previous Year Gross Margin/Total Sales $)>0$ then 1 else 0 \\
Change in Asset Turnover & $\mathrm{IF}($ Current Year Total Sales/Total Asset - Previous Year Total Sales/Total Asset $)>0$ then 1 else 0 \\
\hline
\end{tabular}

All the nine signal outputs are aggregated to arrive at the final F Score for each firm under study. Thus the range of F score obviously lies from a value of 0 to 9 . A firm having F Score above 5, up to 4 and at 5 are classified as firms having strong financial health, weak financial health and neutral respectively. F Score may change over the years depending on the changes in the fundamental signal values obtained from 9 aforesaid parameters. F Score can be presented mathematically as follows:

$$
\begin{gathered}
F \text { Score }=R O A+C F O+\triangle R O A+A C C R U A L+\triangle L E V E R A G E+\triangle L I Q U I D I T Y+\triangle E Q U I T Y+\triangle M A R G I N+ \\
\text { DTURNOVER }
\end{gathered}
$$

Market to Book Value (MTBV): The MTBV ratio is used as a proxy for firm performance measure. This ratio is also known as Price to Book Ratio, which is normally used as a proxy for measuring firm's market performance. It is calculated as Price/Book Ratio $=$ Stock Price Per Share $/$ Shareholders' Equity Per Share or (Book Value of Equity).

Return on Equity (ROE): ROE is used in this study as a measure of the financial performance of a firm for the shareholders. It is an indicator of how efficiently a firm is managing the funds contributed by the shareholders. It is calculated as ROE $=$ Net Income $/$ Shareholder's Equity

Return (Rt): Return is calculated by taking the difference in start of the year price to end of year price as a percentage. To normalize the return data, we have used lognormal return series in our model.

Size: The variable Size refers to the market capitalisation of the firm. It is calculated using the total number of shares outstanding and the market price per share. Size $=$ Number of Shares Outstanding $*$ Market Price per Share

Age of the firm: It refers to the number of years the firm has been in existence since incorporation till the year under observation in the model.

Industry Dummy Variables: There are 8 industry dummy variables used in this study as per the classification provided by CMIE. These dummy variables refer to the industry sectors that the firms in our study belong to. They are as follows: Basic Materials, Communications, Consumer Goods, Diversified, Energy, Industrials, Technology and Utilities. 


\subsection{Model Used}

In this study we engage two sets of panel model where the first set of model tests the contemporaneous effect of the explanatory variables on the explained variables and the second set of model tests the effect of the explanatory variables on the lead explained variables. To investigate whether F Score including other explanatory variables contemporaneously affect the stock performance indicators measured by stock return (Rt), market to Book Value (MTBV) and return on equity (ROE), we estimated three full panel models. The choice of the panel model whether fixed and random effect is decided based on the result of the Hausman test provided in section IV. The panel model specifications are defined as follows:

$$
\begin{aligned}
& M T B V_{i, t}=\alpha_{i}+\beta_{1} \mathrm{FScore}_{\mathrm{i}, \mathrm{t}}+\beta_{2} \mathrm{LnMC}_{\mathrm{i}, \mathrm{t}}+\beta_{3} \mathrm{Ln} \mathrm{Age}_{\mathrm{i}, \mathrm{t}}+\gamma_{\mathrm{j}} \mathrm{D}_{\mathrm{i}, \mathrm{j}}+\varepsilon_{i, t} \\
& R_{i, t}=\alpha_{i}+\beta_{1} \text { F Score }_{i, \mathrm{t}}+\beta_{2} \mathrm{Ln} \mathrm{MC}_{\mathrm{i}, \mathrm{t}}+\beta_{3} \mathrm{Ln} \mathrm{Age}_{\mathrm{i}, \mathrm{t}}+\gamma_{\mathrm{j}} \mathrm{D}_{\mathrm{i}, \mathrm{j}}+\varepsilon_{i, t} \\
& R O E_{i, t}=\alpha_{i}+\beta_{1} \mathrm{~F} \mathrm{Score}_{i, t}+\beta_{2} \mathrm{Ln} \mathrm{MC}_{i, t}+\beta_{3} \mathrm{LnAge}_{i, \mathrm{t}}+\gamma_{\mathrm{j}} \mathrm{D}_{\mathrm{i}, \mathrm{j}}+\varepsilon_{i, t}
\end{aligned}
$$

However, to investigate whether current period $\mathrm{F}$ Score including other explanatory variables affect the lead stock performance indicators measured by stock return (Rt), market to Book Value (MTBV) and return on equity (ROE), we estimated three full panel models. The choice of the panel model whether pooled, fixed and random effect is discussed in the section IV. The panel model specifications are defined as follows:

$$
\begin{aligned}
& M T B V_{i, t+1}=\alpha_{i}+\beta_{1} \mathrm{~F} \mathrm{Score}_{i, \mathrm{t}}+\beta_{2} \mathrm{LnMC}_{\mathrm{i}, \mathrm{t}}+\beta_{3} \mathrm{Ln} \mathrm{Age}_{\mathrm{i}, \mathrm{t}}+\gamma_{\mathrm{j}} \mathrm{D}_{\mathrm{i}, \mathrm{j}}+\varepsilon_{i, t} \\
& R_{i, t+1}=\alpha_{i}+\beta_{1} \mathrm{~F} \mathrm{Score}_{\mathrm{i}, \mathrm{t}}+\beta_{2} \mathrm{Ln} \mathrm{MC}_{\mathrm{i}, \mathrm{t}}+\beta_{3} \mathrm{Ln} \mathrm{Age}_{\mathrm{i}, \mathrm{t}}+\gamma_{\mathrm{j}} \mathrm{D}_{\mathrm{i}, \mathrm{j}}+\varepsilon_{i, t} \\
& R O E_{i, t+1}=\alpha_{i}+\beta_{1} \mathrm{~F} \mathrm{Score}_{i, \mathrm{t}}+\beta_{2} \mathrm{Ln} \mathrm{MC}_{i, \mathrm{t}}+\beta_{3} \mathrm{Ln} \mathrm{Age}_{\mathrm{i}, \mathrm{t}}+\gamma_{\mathrm{j}} \mathrm{D}_{\mathrm{i}, \mathrm{j}}+\varepsilon_{i, t}
\end{aligned}
$$

Where $\mathrm{i}$ stands for the firm, $\mathrm{j}$ stands for industry and $\mathrm{t}$ stands for time.

\section{Results}

\subsection{Preliminary Findings}

This segment analyses the results of descriptive statistics for variables that are used in the empirical examination in the next section. The combined mean ratio of MTBV over the study period is 3.22 which suggest that $72 \%$ of Indian firms' market value is not captured in their book value. This finding supports the empirical findings in many countries (Lev \& Zarowin, 1999. Khanqah, Khosroshahi, \& Ghanavati, 2012, Tripathy, Ranajee, \& Mishra, 2015). The descriptive statistics associated with the variables under the study are reported in Table 2 . The standard deviation of the MTBV of the sample firms during the study period are observed to be 4.26 , which suggests that market to book value of the firms are not stable and varying across the time and firms. The mean and standard deviation of annual return (Rt) and ROEt series are observed to be -0.198 and 0.551 and 14.43 and 23.28 respectively. While the mean age and market capitalisation of the firms under investigation are observed to be 41.4 years and Rs.176905.6 million respectively However, the mean value of the interest variable i.e. F Score is observed to be 5.124 with a minimum of 0 and maximum of 9 . The standard deviation, skewness and kurtosis value of $\mathrm{F}$ score are observed to be $1.45,-0.41$ and 0.04 respectively. Likewise, the skewness and kurtosis statistics associated with all the variables used in this study are not normally distributed. Against this backdrop, to normalize and linearise all the variables we have converted them into natural logarithms.

Table 2. Descriptive statistics for the variables used in the study

\begin{tabular}{lcccccc}
\hline 2010-2015 & F Score & MTBV & $\begin{array}{c}\text { Market Capitalization } \\
\text { (in Million Rupees) }\end{array}$ & ROE & $\begin{array}{c}\text { Age of Firm (in } \\
\text { Years) }\end{array}$ & $\begin{array}{c}\text { Annual Return } \\
\text { (in \%) }\end{array}$ \\
\hline Max & 9 & 80.591 & 5002493 & 452.238 & 115 & 3.165 \\
Min & 0 & 0.0969 & 1903.383 & -195.691 & 3 & -0.864 \\
Mean & 5.124806 & 3.216 & 176905.6 & 14.432 & 41.416 & 0.198 \\
Stdev & 1.446996 & 4.264 & 422595.5 & 23.289 & 23.247 & 0.551 \\
Kurtosis & -0.41476 & 97.187 & 35.03284 & 110.207 & 0.0287 & 5.274 \\
Skew & 0.04 & 7.205 & 5.214629 & 5.176 & 0.858 & 1.731 \\
\hline
\end{tabular}

An attempt is made hereunder to explore a few descriptive statistics for the 1 year ahead lead stock performance indicators which are used as explained variables in the full models (5, 6 and 7). While exploring the mean return difference between the firms having high F Score (6, 7, 8 and 9) and low F Score $(0,1,2,3$ and 4) for the high book to price firms, it is observed that difference across the years are positive except for the year 2012-13. While estimating the mean difference in $\mathrm{MTBVt}+1$ and $\mathrm{ROEt}+1$ under the said framework, it is observed that the 
differences are positive for both the stock performance indicators (Table 3). The study here suggests that firms having high book to price with high F Score tend to outperform the firms having high book to price with low F Score. However, this mean difference across the stock performance indicators may be confounding and thus there is a need of formal statistical test to establish the result. This test would be carried out in the result and discussion segment.

Table 3. Differences in lead stock performance measures based on high book to price with F score across time periods

\begin{tabular}{|c|c|c|c|c|c|c|c|c|c|c|c|}
\hline \multicolumn{4}{|c|}{$\begin{array}{l}\text { High Book to Price with F Score and Lead } \\
\text { MTBV }\end{array}$} & \multicolumn{4}{|c|}{$\begin{array}{l}\text { High Book to Price with F Score Lead } \\
\text { Return }\end{array}$} & \multicolumn{4}{|c|}{$\begin{array}{l}\text { High Book to Price with F Score and Lead } \\
\text { ROE }\end{array}$} \\
\hline $2010-2011$ & MTBV & $\sigma$ & $\mathrm{CV}$ & Return & $\sigma$ & $\mathrm{CV}$ & $\mathrm{N}$ & ROE & $\sigma$ & $\mathrm{CV}$ & $\mathrm{N}$ \\
\hline $\operatorname{High}(\mathrm{H})$ & 3.39 & 4.61 & 135.84 & 0.27 & 0.42 & 158.36 & 13 & 16.61 & 7.27 & 43.74 & 7 \\
\hline Neutral & 2.13 & 1.80 & 84.52 & 0.20 & 0.24 & 122.56 & 6 & 23.64 & 21.05 & 89.05 & 3 \\
\hline Low (L) & 0.97 & 1.50 & 154.09 & -0.13 & 0.47 & -356.80 & 6 & 13.21 & 4.53 & 34.29 & 5 \\
\hline H-L & 2.42 & 3.11 & & 0.40 & -0.04 & & & 3.41 & 2.74 & & \\
\hline 2011-2012 & MTBV & $\sigma$ & $\mathrm{CV}$ & Return & $\sigma$ & $\mathrm{CV}$ & $\mathrm{N}$ & ROE & $\sigma$ & $\mathrm{CV}$ & $\mathrm{N}$ \\
\hline $\operatorname{High}(\mathrm{H})$ & 2.15 & 2.25 & 104.67 & -0.33 & 0.35 & -106.06 & 17 & 12.06 & 4.60 & 38.17 & 5 \\
\hline Neutral & 1.50 & 1.28 & 85.36 & -0.30 & 0.42 & -139.69 & 8 & 15.06 & 3.65 & 24.22 & 4 \\
\hline Low (L) & 0.79 & 0.84 & 106.81 & -0.49 & 0.50 & -103.57 & 12 & 9.01 & 5.70 & 63.23 & 8 \\
\hline H-L & 1.36 & 1.41 & & 0.15 & -0.15 & & & 3.05 & -1.10 & & \\
\hline $2012-2013$ & MTBV & $\sigma$ & $\mathrm{CV}$ & Return & $\sigma$ & $\mathrm{CV}$ & $\mathrm{N}$ & ROE & $\sigma$ & $\mathrm{CV}$ & $\mathrm{N}$ \\
\hline High $(\mathrm{H})$ & 2.20 & 3.08 & 140.15 & 0.24 & 0.20 & 82.94 & 17 & 10.86 & 3.88 & 35.73 & 13 \\
\hline Neutral & 1.40 & 1.62 & 115.78 & 0.18 & 0.33 & 179.37 & 21 & 10.40 & 3.44 & 33.05 & 7 \\
\hline Low (L) & 1.62 & 2.97 & 183.42 & 0.32 & 0.26 & 81.22 & 22 & 10.00 & 4.58 & 45.76 & 14 \\
\hline H-L & 0.58 & 0.11 & & -0.08 & -0.06 & & & 0.85 & -0.70 & & \\
\hline $2013-2014$ & MTBV & $\sigma$ & $\mathrm{CV}$ & Return & $\sigma$ & $\mathrm{CV}$ & $\mathrm{N}$ & ROE & $\sigma$ & $\mathrm{CV}$ & $\mathrm{N}$ \\
\hline $\operatorname{High}(\mathrm{H})$ & 2.36 & 2.96 & 125.47 & 0.18 & 0.37 & 209.09 & 17 & 11.58 & 4.67 & 40.36 & 13 \\
\hline Neutral & 1.99 & 2.88 & 144.68 & 0.11 & 0.31 & 285.88 & 20 & 10.83 & 4.56 & 42.10 & 10 \\
\hline Low (L) & 2.15 & 3.40 & 157.96 & -0.08 & 0.30 & -375.02 & 29 & 9.87 & 5.24 & 53.11 & 11 \\
\hline H-L & 0.21 & -0.43 & & 0.26 & 0.07 & & & 1.71 & -0.57 & & \\
\hline $2014-2015$ & MTBV & $\sigma$ & $\mathrm{CV}$ & Return & $\sigma$ & $\mathrm{CV}$ & $\mathrm{N}$ & ROE & $\sigma$ & $\mathrm{CV}$ & $\mathrm{N}$ \\
\hline High (H) & 4.63 & 4.13 & 89.38 & 0.74 & 0.39 & 53.04 & 19 & 10.54 & 3.33 & 31.60 & 14 \\
\hline Neutral & 3.33 & 5.49 & 164.70 & 0.35 & 0.35 & 98.36 & 19 & 12.50 & 7.76 & 62.09 & 6 \\
\hline Low (L) & 6.10 & 16.27 & 266.81 & 0.43 & 0.51 & 118.21 & 27 & 11.66 & 3.62 & 31.03 & 7 \\
\hline H-L & -1.47 & -12.13 & & 0.31 & -0.12 & & & -1.13 & -0.29 & & \\
\hline
\end{tabular}

High denotes F Score value 6,7,8,9; Neutral is F Score value 5; and Low is F Score value 0,1,2,3,4.

\subsection{Main Findings}

The empirical findings are reported under two subsections. The first subsection presents the findings from the contemporaneous model estimation. The second subsection presents, whether firms with higher F Score with high book to market value in ensuing year tend to have better stock performance in the following years. However, before carrying out the empirical examination, there is a need of choosing appropriate panel models and the following section makes such an attempt.

\subsubsection{Model Selection Criteria}

Table 4 contrasts the output of the pooled Ordinary Least Square (OLS) and four variants of fixed effect estimations such as Least Square Dummy Variable (LSDV), within fixed effect (Within) Models, between fixed effect (between) and fixed effect (FE). All four estimates produce almost different SSE and parameter estimates. However, it reports quite similar standard errors and goodness of fit statistics. While examining the pooled regression data, it is observed that goodness of fit statistic is high and statistically significant but it reports very high standard error and low R square value. Against this backdrop, it points out that the fixed effect model estimations are reasonably better having reasonably high $\mathrm{R}$ square value, low standard error and supported by $\mathrm{F}$ test at acceptable level of significance. Thus, we may use Fixed effect model for our examination.

Further we conduct Breusch-Pegan Lagrange Multiplier (LM) test to examine whether any random effect exists in our data set under the examination. The null hypothesis associated with the random effect model states that firm specific or time specific error variance components are zero (H0: error variance is zero). If the null hypothesis is not rejected, the Pooled Ordinary Least Square Regression would be preferred over the random 
effect model. The Breusch-Pegan Lagrange Multiplier (LM) test value turns out to be 1915.38 and significant at $1 \%$ level of significance, which suggests that the random effect model is preferred over the Pooled Ordinary Least Square regression model.

Now the challenge at hand is whether to model our data under random effect model or fixed effect model. To resolve this issue, we perform Hausman Test, which examines whether individual effects are uncorrelated with any other regressor in the model. If individual effects are correlated with any other regressor, the random effect model violates a Gauss- Markov assumption and the estimates are no longer best linear unbiased estimators. On the other hand, in the fixed effect model as the individual effects are linked to the intercept and regressor, which doesn't violate the Gauss-Markov assumption and thus estimators are still considered to be best linear unbiased estimator. The null hypothesis associated with the Hausman test is 'Random effect model is preferred over the fixed effect model (H0: differences in coefficient is not systematic. The test statistic associated with Hausman test for random effect turns out to be 7.32 and it is statistically significant at $1 \%$ level and thus we reject the null hypothesis. By summarising all the results of pooled regression, fixed effect model and random effect models, we thus conclude to build fixed effect model for the empirical examination.

Table 4. Selecting appropriate base model for empirical examination

\begin{tabular}{|c|c|c|c|c|c|}
\hline Variables & OLS & LSDV & Within & Between & Fixed Effect \\
\hline Intercept & $\begin{array}{c}0.0333 \\
(0.24)\end{array}$ & $\begin{array}{c}-0.6249 * * * \\
(-2.78)\end{array}$ & $\begin{array}{c}0.4453 * * * \\
(5.88)\end{array}$ & $\begin{array}{c}-1.056^{*} \\
(-1.86)\end{array}$ & $\begin{array}{c}1.1771 \text { *** } \\
(6.00)\end{array}$ \\
\hline Lnfs & $\begin{array}{c}0.4260^{* * * *} \\
(5.01)\end{array}$ & $\begin{array}{c}0.3679 * * * \\
(4.49)\end{array}$ & $\begin{array}{c}0.1672 * * * \\
(3.56)\end{array}$ & $\begin{array}{c}1.1103^{* * *} \\
(3.13)\end{array}$ & $\begin{array}{c}0.1672 * * * \\
(3.56)\end{array}$ \\
\hline Basic Materials & & $\begin{array}{c}0.4915 * * \\
(2.51)\end{array}$ & & & \\
\hline Communications & & $\begin{array}{c}0.8926^{* * * *} \\
(4.04)\end{array}$ & & & \\
\hline Consumer Goods & & $\begin{array}{c}1.0259 * * * \\
(5.43)\end{array}$ & & & \\
\hline Energy & & $\begin{array}{c}0.3335 \\
(1.48)\end{array}$ & & & \\
\hline Industrials & & $\begin{array}{c}0.6799 * * * \\
(3.59)\end{array}$ & & & \\
\hline Technology & & $\begin{array}{c}0.9493 * * * \\
(4.51)\end{array}$ & & & \\
\hline Utilities & & $\begin{array}{c}0.2436 \\
(1.13)\end{array}$ & & & \\
\hline F Test (Model) & $25.29 * * *$ & $17.45^{* * * *}$ & $12.68 * * *$ & $12.98 * * *$ & \\
\hline Degrees of Freedom & 1288 & 1281 & 1074 & 1074 & 1074 \\
\hline SSM (Model) & 22.20 & 113.3016 & 2.482 & 0.7036 & 0.1957 \\
\hline SSE (Residual) & 1131.01 & 1039.915 & 236.02 & 149.856 & 210.2 \\
\hline Root MSE (SSE) & 0.931 & 0.901 & 0.912 & 0.8388 & 0.4424 \\
\hline $\mathrm{R}^{\wedge} 2$ & 0.0193 & 0.0982 & 0.0117 & 0.04 & 0.8279 \\
\hline Adjusted $\mathrm{R}^{\wedge} 2$ & 0.0185 & 0.0926 & 0.015 & & 0.8177 \\
\hline F Test (Fixed effect) & & & & & $21.98^{* * *}$ \\
\hline Number of obs. & 1290 & 1290 & 1290 & 1290 & 1290 \\
\hline \multicolumn{3}{|c|}{ LM Test: $M$ value: $1915.38,[\mathrm{p}$ value: $<0.0001]$} & \multicolumn{3}{|c|}{ Hausman Test value: 7.32 [ $\mathrm{p}$ value: $<0.0068$ ] } \\
\hline
\end{tabular}

Note. Figures in the parenthesis are t values.

$*, * *, * * *$ represent level of significance at $1 \%, 5 \%$ and $10 \%$ respectively.

\subsubsection{Full Contemporaneous Model}

Model (2, 3 and 4) are estimated for the full sample period (2009-2015) with the fixed effect model combining all the firms and across 9 different industry categories. In total, 3 fixed effect models are estimated to examine the effect of F Score of the firms across industries and time on stock performance indicators (MTBV i,t, R i,t and ROE i,t) contemporaneously. In doing so, it is expected that F Score as a composite measure for financial health of the firms would significantly influence financial performances measured across aforesaid stock performance indicators. The estimated results of these models are reported in Table 5.

The observed $\mathrm{R}$ square and $\mathrm{F}$ values for model 2, 3 and 4 suggest that explanatory variables used in the models are significantly explaining the change in all the stock performance measures engaged under the study. The 
estimated results under these models also suggest that the coefficient attached to F Score is observed to be statistically significant at accepted levels for all the stock performance regressions. The sign attached to the $\mathrm{F}$ score across these models are observed to be positive, which suggests that higher is the F Score better is the firms contemporaneous stock performance and vice versa. These results lend support to our first set of alternative hypotheses under $\mathrm{H} 1$ ( $\mathrm{H} 1 \mathrm{a}: \mathrm{H} 1.1 \mathrm{a} \mathrm{H} 1.2 \mathrm{a}$ and $\mathrm{H} 1.3 \mathrm{a}$ ) that there is a positive relationship between $\mathrm{F}$ Score \& contemporaneous stock performance measures (MTBVt, Rt and ROEt).

Table 5. Contemporaneous effect of F score on stock performance measures

\begin{tabular}{|c|c|c|c|}
\hline \multirow{2}{*}{ Independent Variables } & \multicolumn{3}{|c|}{ Dependant Variables } \\
\hline & Ln (MTBVt) & Ln(ROEt) & Ln (Rt) \\
\hline Ln (F Score) & $\begin{array}{c}0.3548 * * * \\
(5.06)\end{array}$ & $\begin{array}{c}.4446^{* * * *} \\
(9.80)\end{array}$ & $\begin{array}{c}0.3182 * * * \\
(7.23)\end{array}$ \\
\hline Ln (Market Cap) & $\begin{array}{c}0.3027 * * * \\
(21.45)\end{array}$ & $\begin{array}{c}0.2262 * * * \\
(11.59)\end{array}$ & $\begin{array}{c}0.0414 * * * \\
(4.67)\end{array}$ \\
\hline Ln(Age) & $\begin{array}{c}0.0505 \\
(1.25)\end{array}$ & $\begin{array}{c}-0.0439 \\
(0.79)\end{array}$ & $\begin{array}{c}-0.0105 \\
(-0.41)\end{array}$ \\
\hline Basic Materials & $\begin{array}{c}0.2505 \\
(1.49)\end{array}$ & $\begin{array}{c}-0.0693 \\
(-0.3)\end{array}$ & $\begin{array}{c}-0.0654 \\
(-0.62)\end{array}$ \\
\hline Communications & $\begin{array}{c}0.5123 * * * \\
\quad(2.60)\end{array}$ & $\begin{array}{c}-0.8529 * * * \\
(-3.13)\end{array}$ & $\begin{array}{c}-0.2147^{*} \\
(-1.74)\end{array}$ \\
\hline Consumer Goods & $\begin{array}{c}0.7576^{* * * *} \\
(4.64)\end{array}$ & $\begin{array}{c}-0.1802 \\
(-0.8)\end{array}$ & $\begin{array}{c}-0.0069 \\
(-0.07)\end{array}$ \\
\hline Energy & $\begin{array}{c}-0.2748 \\
(-1.4)\end{array}$ & $\begin{array}{c}-1.6129 * * \\
(-2.26)\end{array}$ & $\begin{array}{c}-0.2561 * * \\
(-2.08)\end{array}$ \\
\hline Industrials & $\begin{array}{c}0.5315^{* * *} \\
\quad(3.27)\end{array}$ & $\begin{array}{c}-0.2037 \\
(-0.9)\end{array}$ & $\begin{array}{c}-0.0332 \\
(-0.32)\end{array}$ \\
\hline Technology & $\begin{array}{c}0.6968 * * * \\
(3.78)\end{array}$ & $\begin{array}{l}0.3122 \\
-1.23\end{array}$ & $\begin{array}{c}0.0648 \\
(0.56)\end{array}$ \\
\hline Utilities & $\begin{array}{c}-0.1135 \\
(-0.61)\end{array}$ & $\begin{array}{c}-0.4588^{*} \\
(-1.78)\end{array}$ & $\begin{array}{c}-0.2165^{*} \\
(-1.85)\end{array}$ \\
\hline Constant & $\begin{array}{c}-3.7935 * * * \\
(-13.52)\end{array}$ & $\begin{array}{c}-1.5805 * * * \\
(-4.07)\end{array}$ & $\begin{array}{c}-0.6399 \text { *** } \\
(-3.63)\end{array}$ \\
\hline Adj R-squared & 0.3347 & 0.1933 & 0.077 \\
\hline F Value & $65.85^{* * *}$ & $31.89^{* * *}$ & $10.36^{* * *}$ \\
\hline
\end{tabular}

Note. Figures in the parenthesis are $\mathrm{t}$ values.

$*, * *, * * *$ represent level of significance at $1 \%, 5 \%$ and $10 \%$ respectively.

\subsubsection{Full Lead Model}

To test the second objective we have estimated the full model with 1 year ahead lead stock performance indicators as dependent variables and current year F Score and other explanatory variables including industry dummies as independent variables. The model (5, 6 and 7) is estimated for the full sample period (2009-2015) with the pooled regression combining the firms and across 8 different industry categories and the estimated results are captured in Table 6 .

Table 6: Effect of F score on future stock performance measures for the high book to price firms

\begin{tabular}{cccc}
\hline \multirow{2}{*}{ Explanatory Variables } & \multicolumn{3}{c}{ Explained variables } \\
\cline { 2 - 4 } & Ln $(\mathbf{R t + 1})$ & Ln $(\mathbf{M T B V t + 1})$ & Ln(ROEt+1) \\
\hline \multirow{2}{*}{ Ln (F Score) } & $0.0954^{* *}$ & $0.3006^{* * *}$ & $0.0743^{*}$ \\
& $(1.99)$ & $(3.56)$ & $(1.85)$ \\
Ln (Market Cap) & -0.0082 & $0.256^{* * *}$ & -0.008 \\
& $(-1.13)$ & $(15.04)$ & $(-1.15)$ \\
Ln(Age) & $-0.0458^{* *}$ & $-0.0913^{*}$ & $-0.055^{* *}$ \\
& $(2.22)$ & $(1.94)$ & $(2.043)$ \\
Basic Materials & -0.0474 & 0.3065 & $0.062^{*}$ \\
Communications & $(-0.55)$ & $(1.53)$ & $(1.82)$ \\
& -0.0403 & $0.6362^{* * *}$ & 0.0076 \\
\end{tabular}




\begin{tabular}{|c|c|c|c|}
\hline Consumer Goods & 0.0492 & $0.8642 * * *$ & 0.01227 \\
\hline Consumer Goods & $(0.59)$ & $(4.44)$ & $(1.22)$ \\
\hline Energy & $\begin{array}{l}-0.1227 \\
(-122)\end{array}$ & $\begin{array}{l}-0.2116 \\
(-0.191)\end{array}$ & $\begin{array}{c}-0.0498 \\
(-0.6)\end{array}$ \\
\hline Industrials & $\begin{array}{c}-0.0498 \\
(-0.6)\end{array}$ & $\begin{array}{c}0.5485^{* * * *} \\
(2.83)\end{array}$ & $\begin{array}{c}0.177 * * * \\
(2.57)\end{array}$ \\
\hline Technology & $\begin{array}{c}0.1191 \\
(1.26)\end{array}$ & $\begin{array}{c}0.7817 * * * \\
(3.57)\end{array}$ & $\begin{array}{c}0.0314 * \\
(1.72)\end{array}$ \\
\hline Utilities & $\begin{array}{c}-0.1381 \\
(-1.44)\end{array}$ & $\begin{array}{c}-0.1314 \\
(-0.59)\end{array}$ & $\begin{array}{c}-0.216 \\
(-1.5)\end{array}$ \\
\hline Constant & $\begin{array}{c}-0.2486 \\
(-1.73)\end{array}$ & $\begin{array}{c}-3.4403 * * * \\
(-10.32)\end{array}$ & $\begin{array}{c}-2.3445 * * * \\
(-10.45)\end{array}$ \\
\hline Adj R-squared & 0.0374 & 0.259 & 0.0198 \\
\hline F Value & $6.01 * * *$ & $38.57 * * *$ & $3.45 * *$ \\
\hline
\end{tabular}

Note. Figures in the parenthesis are t values.

$*, * *, * * *$ represent level of significance at $1 \%, 5 \%$ and $10 \%$ respectively.

While estimating these models, we intend to examine the effect of high F Score for the firms having high book to price value across the industries and time on one period lead stock performance indicators (MTBV i,t+1, R i,t+1 and ROE $i, t+1)$. The F Score obtained against each firm in each period is categorised into three different categories. The firms having F Score above 5 , up to 4 and at 5 are classified as firms with strong financial health, weak financial health and neutral respectively. Further, a firm having book to price ratio above 1 and otherwise are categorised as high book to price firms and low book to price firms. It is expected that firms having better financial health represented by high F Score with high book to market value can significantly shift the future stock performance in favour of the investors. The estimated results of these models are reported in Table 6.

The observed $\mathrm{R}$ square and $\mathrm{F}$ values for model 5, 6 and 7 suggests that explanatory variables used in the models are significantly explaining the change in all the stock future performance measures engaged under the study. It is also observed that the coefficient attached to F Score is observed to be positive and statistically significant at accepted levels for all the stock performance regressions. However, the F Score coefficient attached to return regression is statistically significant at $10 \%$ level of significance which shows that F Score has weak explanatory power to influence the firms' future return compared to two other stock performance indicators. The result here affirms that future stock performance of firms having higher book to market value would be better for the firms having higher $\mathrm{F}$ score as against the firms having lower F Score. These results lend support to our first set of alternative hypotheses $\mathrm{H} 2$ at least at $10 \%$ level of significance (H2a: $\mathrm{H} 2.1 \mathrm{a} \mathrm{H} 2.2 \mathrm{a}$ and $\mathrm{H} 2.3 \mathrm{a})$. That means there is a positive relationship between current $\mathrm{F}$ Score and future stock performance measures $(\mathrm{MTBVt}+1, \mathrm{Rt}+1$ and $\mathrm{ROEt}+1)$.

\section{Robustness Tests}

An unobservable correlated with F score and firm performance measures may be present and would make coefficient estimates biased. hence, to justify our results two robustness tests are attempted i.e.one test is calibrated with F Score's concurrent measure and other test calibrated with a year specific cross section regression where a current period (2016) firm performance measure is regressed on the previous period (2015) F score. Further a 'current period enterprise value (EV) as a control variable is also included in the second model. The logic of including EV into the second model emanates from the fact that the EV has a direct linkage with the firm performance. Thus the first model is estimated with concurrent high $\mathrm{F}$ score with the contemporaneous firm performance measures. The result suggests that firms with high F score in the current period don't have any statistically significant effect on firm performance measures (Panel A of Table 7). The results here corroborate our findings that a firm high F score in the current period expected to perform better in the future. Second, robustness model is developed where each firm performance measures of the year 2016 are regressed separately on F scores of 2015. It is observed that the firm with high F score in the year 2015 significantly influencing the firm performance in the year 2016 (Panel B of Table 7). Overall analysis suggests that our estimated results are robust and unbiased. 
Table 7: Robustness examination results for firm performance measures and F score

\begin{tabular}{|c|c|c|c|}
\hline \multicolumn{4}{|c|}{ Panel A } \\
\hline Description & MTBV(t) & Return $(\mathrm{t})$ & ROE (t) \\
\hline & 3.027 & -1.221 & -2.446 \\
\hline \multirow[t]{2}{*}{ Intercept } & $(0.383)$ & $(-1.259)$ & $(-0.038)$ \\
\hline & 0.315 & 0.823 & 12.582 \\
\hline $\operatorname{LnFS}(\mathrm{t})$ & $(0.079)$ & $(1.396)$ & $(0.388)$ \\
\hline F value & 0.006 & $2.828^{*}$ & 0.151 \\
\hline R Square & 0.000 & 0.012 & 0.006 \\
\hline \multicolumn{4}{|c|}{ Panel B } \\
\hline \multirow[t]{2}{*}{ Description } & LnMTBV t+1 & $\mathrm{RETt}+1$ & ROE $t+1$ \\
\hline & $-12.592 * * *$ & -0.045 & $-0.530 * *$ \\
\hline \multirow[t]{2}{*}{ Intercept } & $(-2.577)$ & $(-0.183)$ & $(-2.014)$ \\
\hline & $6.434 * *$ & $0.571 * * *$ & $0.779 * * *$ \\
\hline \multirow[t]{2}{*}{ LNFS } & $(2.013)$ & $(3.128)$ & $(4.024)$ \\
\hline & $1.079 * * *$ & $0.037 * *$ & $0.095 * * *$ \\
\hline LEV & $(3.275)$ & $(2.234)$ & $(2.680)$ \\
\hline Adjusted R Square & 0.046 & 0.075 & 0.062 \\
\hline F Statistic & $6.214 * * *$ & $8.654 * * *$ & $8.098 * * *$ \\
\hline
\end{tabular}

\section{Conclusion}

The study has engaged the panel data model to analyse the impact of high Piotroski Score on current and future stock return $\left(R_{t}\right.$ and $\left.R_{t+1}\right)$, return on equity $\left(R E_{t}\right.$ and $\left.R O E_{t+1}\right)$ and market to book value $\left(M_{T B V}\right.$ and $\left.M T B V_{t+1}\right)$ as stock performance measures. The study concludes that $\mathrm{F}$ Score as a simple accounting-based fundamental analysis strategy applied to firms having high book to market value with high F score can shift the distribution of returns earned by an investor in the Indian market. The impact of this single index F Score measure is observed to be statistically significant when applied to future stock valuation rather than on the future stock return at least at $5 \%$ level of significance. . The result here affirms that future stock performance of firms having higher book to market value would be better for the firms having higher F score as against the firms having lower F Score. These results lend support to our second set of alternative hypotheses at least at $10 \%$ level of significance (H2a: $\mathrm{H} 2.1 \mathrm{a} \mathrm{H} 2.2 \mathrm{a}$ and $\mathrm{H} 2.3 \mathrm{a}$ ) that there is a positive relationship between F Score \& future stock performance measures (MTBVt+1 Rt+1 and ROEt+1). To the best of our knowledge, until now not much systematic study has empirically investigated the effect of $\mathrm{F}$ score on stock performance in the Indian equity market. However this study is not free from limitations. The convergence of data from different sources may have potential problems and our estimated results may be questioned. Thus there is a need for further research to look into this issue more carefully. The results may be further validated with the extended time period and including more firms into the sampling framework. However, the outcome of the study may help the individual value investors, mutual fund managers and value investing strategists who have presence in the Indian market. This paper contributes to the literature by providing evidence and applicability of value investment strategy based on F Score in the emerging market context.

\section{References}

Chen, N., \& Zhang, F. (1998). Risk and return of value stocks. The Journal of Business, 71(4), 501-535. https://doi.org/10.1086/209755

De Bondt, W. F., \& Thaler, R. (1985). Does the stock market overreact? The Journal of Finance, 40(3), 793-805. https://doi.org/10.1111/j.1540-6261.1985.tb05004.x

De Bondt, W. F., \& Thaler, R. (1987). Further evidence on investor overreaction and stock market seasonality. The Journal of Finance, 42(3), 557-581. https://doi.org/10.1111/j.1540-6261.1987.tb04569.x

De, S., Gondhi, N. R., \& Sarkar, S. (2011). Behavioral biases, investor performance, and wealth transfers between investor groups. Investor Performance, and Wealth Transfers between Investor Groups (November 15, 2011). https://doi.org/10.2139/ssrn.2022992

Fama, E. F., \& French, K. R. (1992). The cross-section of expected stock returns. The Journal of Finance, 47(2), 427-465. https://doi.org/10.1111/j.1540-6261.1992.tb04398.x

Fama, E. F., \& French, K. R. (1993). Common risk factors in the returns on stocks and bonds. Journal of Financial Economics, 33(1), 3-56. https://doi.org/10.1016/0304-405x(93)90023-5

Fama, E. F., \& French, K. R. (1995). Size and book to market factors in earnings and returns. The Journal of 
Finance, 50(1), 131-155. https://doi.org/10.1111/j.1540-6261.1995.tb05169.x

Fama, E. F., \& French, K. R. (1996). Multifactor explanations of asset pricing anomalies. The Journal of Finance, 51(1), 55-84. https://doi.org/10.1111/j.1540-6261.1996.tb05202.x

Fama, E. F., \& French, K. R. (1998). Value versus growth: The international evidence. The Journal of Finance, 53(6), 1975-1999. https://doi.org/10.1111/0022-1082.00080

Fama, E. F., \& French, K. R. (2012). Size, value, and momentum in international stock returns. Journal of Financial Economics, 105(3), 457-472. https://doi.org/10.1016/j.jfineco.2012.05.011

Hayes, R. (1998). The impact of trading commission incentives on analysts' stock coverage decisions and earnings forecasts. Journal of Accounting Research, 36(2), 299-320. https://doi.org/10.2307/2491479

Jaspal, S. K. K. (2015). Adding value to value stocks in Indian stock market: An empirical analysis. International Journal of Law and Management, 57(6), 621-636. https://doi.org/10.1108/ijlma-09-2014-0055

Jegadeesh, N., \& Titman, S. (1993). Returns to buying winners and selling losers: Implications for stock market efficiency. The Journal of Finance, 65-91. https://doi.org/10.1111/j.1540-6261.1993.tb04702.x

Jegadeesh, N., \& Titman, S. (2001). Profitability of momentum strategies: An evaluation of alternative explanations. The Journal of Finance, 56(2), 699-720. https://doi.org/10.1111/0022-1082.00342

Koch, A. S. (2002). Financial distress and the credibility of management earnings forecasts. https://doi.org/10.2139/ssrn.415580.

Kothari, S. P., Shanken, J., \& Sloan, R. G. (1995). Another look at the cross-section of expected stock returns. The Journal of Finance, 50(1), 185-224. https://doi.org/10.1111/j.1540-6261.1995.tb05171.x

Lakonishok, J., Shleifer, A., \& Vishny, R. W. (1994). Contrarian investment, extrapolation, and risk. The Journal of Finance, 49(5), 1541-1578. https://doi.org/10.1111/j.1540-6261.1994.tb04772.x

Lev, B., \& Zarowin, P. (1999). The boundaries of financial reporting and how to extend them. Journal of Accounting Research, 37(2), 353-385. https://doi.org/10.2307/2491413

McNichols, M., \& O'Brien, P. C. (1997). Self-selection and analyst coverage. Journal of Accounting Research, 35, 167-199. https://doi.org/10.2307/2491460

Miller, G. S. (2002). Earnings performance and discretionary disclosure. Journal of Accounting Research, 40(1), 173-204. https://doi.org/10.1111/1475-679x.00043

Piotroski, J. (2000). Value investing: The use of historical financial statement information to separate winners from losers. Journal of Accounting Research, 38, 1-41. https://doi.org/10.2307/2672906

Pontiff, J., \& Lawrence, D. S. (1998). Book-to-market ratios as predictors of market returns. Journal of Financial Economics, 49(2), 141-160. https://doi.org/10.1016/s0304-405x(98)00020-8

Porta, R. L., Lakonishok, J., Shleifer, A., \& Vishny, R. (1997). Good news for value stocks: Further evidence on $\begin{array}{lllll}\text { market efficiency. The Journal of } & \text { Finance, }\end{array}$ https://doi.org/10.1111/j.1540-6261.1997.tb04825.x

Rosenberg, B., Reid, K., \& Lanstein, R. (1985). Persuasive evidence of market inefficiency. The Journal of Portfolio Management, 11(3), 9-16. https://doi.org/10.3905/jpm.1985.409007

Salteh, H. M., Ghanavati, E., Khanqah, V. T., \& Khosroshahi, M. A. (2012). Capital structure and firm performance; Evidence from Tehran Stock Exchange. International Proceedings of Economics Development \& Research, 43, 225-230.

Sehgal, S., \& Balakrishnan, I. (2002). Contrarian and momentum strategies in the Indian capital market. Vikalpa, 27(1), 13-20. https://doi.org/10.1177/0256090920020103

Tripathy, T., Ranajee, \& Mishra, A. K. (2015). Time-varying momentum return in Indian stock market. International Journal of Behavioural Accounting and Finance, 5(3-4), 203-241. https://doi.org/10.1504/ijbaf.2015.075330

\section{Copyrights}

Copyright for this article is retained by the author(s), with first publication rights granted to the journal.

This is an open-access article distributed under the terms and conditions of the Creative Commons Attribution license (http://creativecommons.org/licenses/by/4.0/). 